\title{
Beyond the News: Health Risks of Climate Change
}

\author{
Kristie L. Ebi*
}

\section{INTRODUCTION}

Climate change is affecting the health of millions of people through altering the geographic distribution and incidence of climate-sensitive health outcomes, including through injuries, illnesses, and deaths due to extreme weather events, food-, water-, and vectorborne diseases, air pollution, aeroallergens, and malnutrition (1). The magnitude of impacts is projected to increase as the climate continues to change. The scope and scale of projected impacts mean that climate change will touch the professional and personal lives of many public health and health care professionals. Avoiding, preparing for, and effectively responding to the health risks of climate change will require broad engagement of scientists, decision-makers, and the public. Achieving this engagement means that increased scientific literacy is needed of the causes and implications of climate change for human health.

There are growing numbers of assessments of the potential health impacts of climate change (1-4) and summaries for various audiences (5). Instead of summarizing current knowledge of the causes and consequences for human health of anthropogenic climate change, this paper will highlight a few issues that may help with understanding the human health impacts of climate change.

\section{Energy drives climate change as well as its consequences}

Energy refers to both the energy derived from burning fossil fuels, which, along with deforestation, is the primary cause of anthropogenic climate change, and to the resulting increased energy within the climate system that is manifest in the form of increased temperatures,

*To whom correspondence should be addressed:

Kristie L. Ebi, Ph.D., MPH

ESS, LLC

5249 Tancreti Lane

Alexandria, VA 22304

USA

Email: krisebi@essllc.org alterations of the hydrologic cycle, and more frequent and intense extreme weather events.

The principal driving force for weather and climate is the uneven warming of the Earth's surface (due to the angle of rotation). Complex and changing atmospheric and oceanic patterns redistribute the absorbed solar energy from the equator to the poles. In addition, some absorbed energy is reradiated as long-wave (infrared) radiation. Some of this infrared radiation is then absorbed by the atmospheric greenhouse gases (including water vapour, carbon dioxide, methane, nitrous oxide, halocarbons, and ozone) and reradiated back to the Earth, thereby adding additional energy to the atmosphere and oceans. This greenhouse effect warms the surface by more than would be achieved by incoming solar radiation alone and raises the global average surface temperature to its current $15^{\circ} \mathrm{C}$ (6). Without this warming, the Earth's diurnal temperature range would increase dramatically, and the global average surface temperature would be about $33^{\circ} \mathrm{C}$ colder. Increasing concentrations of greenhouse gases are increasing the energy in the atmosphere, further warming the planet.

Current concentrations of atmospheric $\mathrm{CO}_{2}$ and ethane far exceed pre-industrial values found in polar ice core records dating back 650,000 years; the concentration of atmospheric $\mathrm{CO}_{2}$ has increased from a pre-industrial value of about $280 \mathrm{ppm}$ to $379 \mathrm{ppm}$ in 2005 (7). Since 1750, it is estimated that about $2 / 3 \mathrm{rd}$ of anthropogenic $\mathrm{CO}_{2}$ emissions have come from fossil fuel burning and about $1 / 3$ rd from land use change. Ambient temperatures increased $0.74^{\circ} \mathrm{C}$ worldwide over the period 1906-2005. The rate of warming averaged over the past 50 years $\left(0.13^{\circ} \mathrm{C}+0.03^{\circ} \mathrm{C}\right.$ per decade) is nearly twice that for the last 100 years (Figure 1), and at least six times faster than at any time during the 2,000 years.

\section{The Earth is committed to decades of climate change}

Figure 2, from the Intergovernmental Panel on 

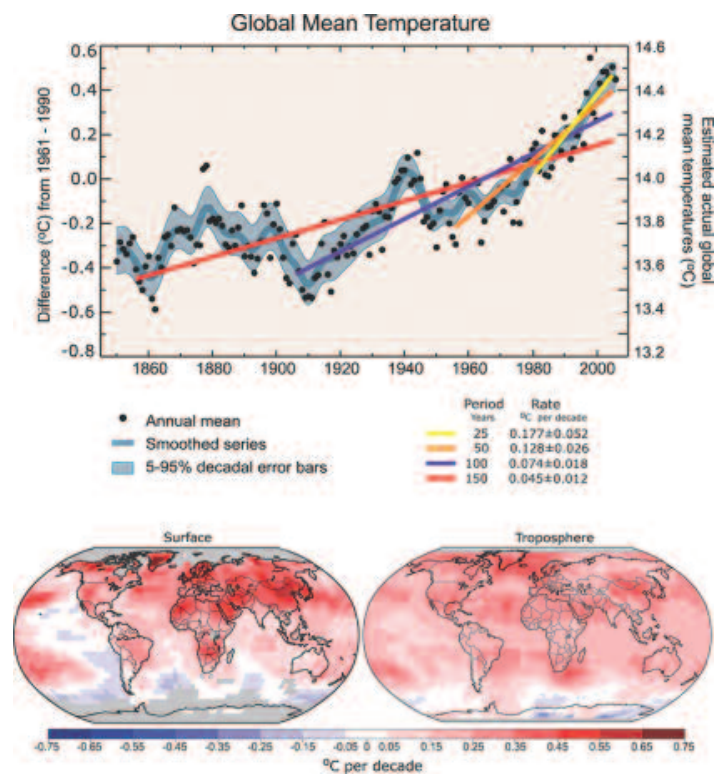

Figure 1: Figure 1: Global mean temperature increase $\left({ }^{\circ} \mathrm{C}\right)$ from 1850 to 2005 (7). Annual global mean temperatures (black dots) with linear fits to the data. The left axis shows temperature anomalies relative to 1961-1990 and the right hand axis shows estimated actual temperatures. Linear trends are shown for the last 25 (yellow), 50 (orange), 100 (magenta), and 150 (red) years. The smoothed blue curve shows decadal variations. The total temperature increase from the period 1850 to 1899 to the period 2001 to 2005 is $0.76^{\circ} \mathrm{C}+$ $0.19^{\circ} \mathrm{C}$.

Climate Change (IPCC), shows projected temperature changes over this century based on different scenarios of greenhouse gas emissions (7). These scenarios are based on differing assumptions of future demographic, economic, and technology changes that determine the amount of fossil fuels that will be burned. The IPCC projected that the global mean temperature of the Earth

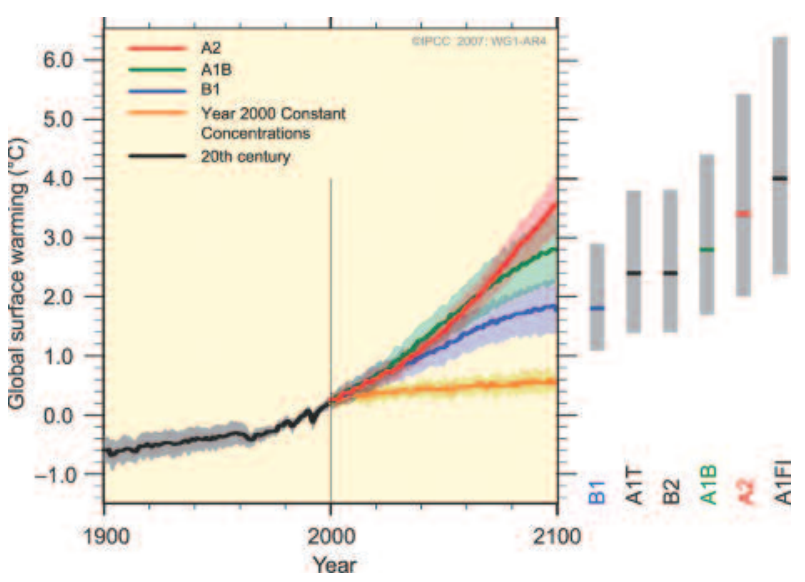

Figure 2: Observed and Projected Global Mean Surface Temperatures $\left({ }^{\circ} \mathrm{C}\right), 1900$ to 2100 . Solid lines are multi-model global averages of surface warming (relative to 1980-1999) for the scenarios $\mathrm{A} 2$, A1B and B1, shown as continuations of the 20th century simulations. Shading denotes the \pm 1 standard deviation range of individual model annual averages. The orange line is for model runs where concentrations were held constant at year 2000 values. The grey bars at right indicate the best estimate (solid line within each bar) and the likely range assessed for the six SRES (Standardized Reference Emission Scenarios) marker scenarios. would increase by the end of the 21st century by between 1.1 and $6.4^{\circ} \mathrm{C}$ (7). This projected rate of warming is much larger than the observed changes during the 20th century and is very likely to be without precedent during at least the last 10,000 years.

The orange line on the figure is the climate change commitment or the amount of warming that will occur no matter the degree to which greenhouse gas emissions are reduced over the next few decades. This commitment is due to the inherent inertia in the climate system. Natural processes currently remove about half the incremental anthropogenic $\mathrm{CO} 2$ added to the atmosphere annually; the balance is removed over one to two hundred years (7). The Earth is committed to nearly as much warming as has already occurred.

\section{Climate change is about changes in long-term averages as well as extremes}

Climate change will increase both temperatures and climate variability. Assuming a normal distribution of surface temperature, climate change could increase mean temperature without a change in the variability (e.g. the shape of the curve would remain the same but would be shifted towards warmer temperatures); increase the variability without a change in mean temperature (e.g. the shape of the curve would become flatter, thus increasing the number of both hot and cold weather extremes); or shift both the mean and the variability of temperature, which would result in slightly less cold weather and substantially more hot and record hot weather. There is growing concern that

Standardized Reference Emission Scenarios

Standardized Reference Emission Scenarios (SRES) were developed by the Intergovernmental Panel on Climate Change as alternative images of how the future might unfold.12 Four different narrative storylines were developed to describe the relationships between greenhouse gas emission driving forces and their evolution. Probabilities or likelihood were not assigned to the individual scenarios. There is no single most likely, or best guess, scenario. None of the scenarios represents an estimate of a central tendency for all driving forces or emissions.

Each SRES storyline assumes a distinctly different direction for future development, such that the four storylines differ in increasingly irreversible ways. The storylines were created along two dimensions - global vs. regional development patterns and whether economic or environmental concerns would be primary. It is important to note that the scenarios do not cover all possible future worlds. For example, there is no SRES world in which absolute incomes are constant or falling. The A2 and B2 storylines are frequently used in modeling health impacts.

The A2 storyline describes a very heterogeneous world with an underlying theme of self-reliance and preservation of local identities. Fertility patterns across regions vary slowly, resulting in continuously increasing global population. Economic development is primarily regionally oriented and per capita economic growth and technological change are fragmented and slower compared with the other scenarios.

The B2 storyline describes a world in which the emphasis is on local solutions to economic, social, and environmental sustainability. It is a world with continuously increasing global population (at a rate slower than A2), intermediate levels of economic development, and less rapid and more diverse technological change. 
future weather patterns will resemble this last pattern and that what is currently considered an extreme event may become common.

The IPCC concluded that climate change has already increased the frequency, intensity, and duration of some extreme weather events (Table 1) (7). This increase in extremes is expected to accelerate with additional climate change, and will have obvious implications for human health.

\section{The future will not be like the past}

A main consequence of climate change for human societies is that the future will not be like the past. Most of our infrastructure was built assuming that the weather in the next few decades will pretty much be like the weather today, resulting in hospitals, power plants, and other critical infrastructure in some regions now lying in flood plains and along coastal regions where sea level rise and storm surges put them at risk of inundation. Changing climatic patterns also are not taken into consideration in critical public health and health care programs, such as surveillance and control activities.

Research is documenting climate change impacts on the atmosphere, oceans and biosphere on which human health and well-being depend (7). Few health organizations and agencies explicitly incorporate the potential risks of and responses to climate change into their programs and activities. Increasing mortality from heatwaves and other extreme weather events, changes in the geographic range and incidence of climatesensitive infectious diseases, increasing morbidity and mortality from poor air quality, and other health impacts will require modification of current public health programs $(8,9)$ and training of health care providers to be prepared for patients presenting with currently unexpected climate-sensitive health outcomes (5).

\section{Health impacts will depend on the local context}

The causal chain from climate change to changing patterns of health determinants and outcomes is complex and includes factors such as wealth, distribution of income, status of the public health infrastructure, and access to medical care (10). Therefore, the severity of future impacts will be determined by changes in climate as well as by concurrent changes in nonclimatic factors. This means that impacts will vary by location; one exposureresponse relationship may not explain observed impacts across regions or across vulnerable groups. One key determinant of the extent of impacts is the status of the public health infrastructure. For example, Fleury et al. (11) found strong non-linear associations between ambient temperature and the occurrence of Salmonella, pathogenic Escherichia coli, and Campylobacter in Alberta. In Newfoundland-Labrador, a relationship was found only for Campylobacter. The number of additional cases due to climate change can be projected, assuming the relationships remain the same with higher temperatures. However, the number of additional cases

\begin{tabular}{|l|l|l|l|l|}
\hline $\begin{array}{l}\text { Phenomenon and Direction of } \\
\text { Trend }\end{array}$ & $\begin{array}{l}\text { Likelihood that trend } \\
\text { occurred in 20th } \\
\text { Century }\end{array}$ & $\begin{array}{l}\text { Likelihood of a Human } \\
\text { Contribution to Observed } \\
\text { Trend }\end{array}$ & D & $\begin{array}{l}\text { Likelihood of Future Trend } \\
\text { Based on Projections for } \\
\text { 21st Century }\end{array}$ \\
\hline $\begin{array}{l}\text { Warmer and fewer cold days and } \\
\text { nights over most land areas }\end{array}$ & Very likely & Likely & Virtually certain \\
\hline $\begin{array}{l}\text { Warmer and more frequent hot days } \\
\text { and nights over most land areas }\end{array}$ & Very likely & Likely (nights) & Virtually certain \\
\hline $\begin{array}{l}\text { Warm spells / heatwaves: } \\
\text { frequency increases over most land } \\
\text { areas }\end{array}$ & Likely & More likely than not & & Very likely \\
\hline $\begin{array}{l}\text { Heavy precipitation events: } \\
\text { frequency (or proportion of total } \\
\text { rainfall from heavy falls) increases } \\
\text { over most areas }\end{array}$ & Likely & More likely than not & & Very likely \\
\hline Area affected by droughts increases & $\begin{array}{l}\text { Likely in many regions } \\
\text { since } 1970 \text { s }\end{array}$ & More likely than not & $*$ & Likely \\
\hline $\begin{array}{l}\text { Intense tropical cyclone activity } \\
\text { increases }\end{array}$ & $\begin{array}{l}\text { Likely in many regions } \\
\text { since } 1970 \text { s }\end{array}$ & More likely than not & & Likely \\
\hline $\begin{array}{l}\text { Increased incidence of extreme high } \\
\text { sea level }\end{array}$ & Likely & More likely than not & & Likely \\
\hline
\end{tabular}

Table 1: Recent Trends, Assessment of Human Influence, and Projections of Extreme Weather and Climate Events for Which There is Evidence of an Observed Late-20th Century Trend (7).

*An asterisk in column D indicates that formal detection and attribution studies were used, along with expert judgment, to assess the likelihood of a discernible human influence. 


\begin{tabular}{|l|l|}
\hline \multicolumn{1}{|c|}{$\begin{array}{c}\text { Climate-Sensitive } \\
\text { Health Outcome }\end{array}$} & \multicolumn{1}{|c|}{ Particularly Vulnerable Groups } \\
\hline $\begin{array}{l}\text { Heat-related } \\
\text { illnesses and deaths }\end{array}$ & $\begin{array}{l}\text { Elderly, chronic medical conditions, infants } \\
\text { and children, pregnant women, urban and } \\
\text { rural poor, outdoor workers }\end{array}$ \\
\hline $\begin{array}{l}\text { Diseases and deaths } \\
\text { related to air quality }\end{array}$ & $\begin{array}{l}\text { Children, pre-existing heart or lung disease, } \\
\text { diabetes, athletes, outdoor workers }\end{array}$ \\
\hline $\begin{array}{l}\text { Illnesses and deaths } \\
\text { due to extreme } \\
\text { weather events }\end{array}$ & $\begin{array}{l}\text { Poor, pregnant women, chronic medical } \\
\text { conditions, mobility and cognitive constraints }\end{array}$ \\
\hline $\begin{array}{l}\text { Water- and } \\
\text { foodborne illness }\end{array}$ & Immunocompromised, elderly, infants \\
\hline Vectorborne illnesses & Children, outdoor workers \\
\hline Lyme disease & Rural poor, occupational groups \\
\hline Hantavirus & Infants, elderly \\
\hline Dengue & $\begin{array}{l}\text { Whildren, immunocompromised, pregnant } \\
\text { women, genetic }\end{array}$ \\
\hline Malaria &
\end{tabular}

Table 2: Climate-Sensitive Health Outcomes and Particularly Vulnerable Groups (2).

actually experienced will depend on the effectiveness and timeliness of additional public health interventions to reduce cases of enteric disease.

\section{Not everyone is equally vulnerable to the health risks of climate change}

Sub-populations that are most vulnerable to the health impacts of climate change depend on the region, the health outcome, and population characteristics, including human, institutional, social, and economic capacity (8). Individual vulnerability depends on genetic, developmental, acquired, and socioeconomic factors. In general, the most vulnerable include children, older adults, those with chronic medical conditions, socially disadvantaged individuals, those living in water-stressed and coastal and low-lying areas, and populations highly dependent on natural and resources. Table 2 summarizes vulnerable populations by health outcome.

\section{Public health and health care systems need to be strengthened}

Responsibility for the prevention of climate-sensitive health risks rests with individuals, community and state governments, national agencies, and others. The primary response in most cases will be to strengthen current programs and activities to reduce the burden of climate-sensitive health outcomes, such as improving food-, water-, and vectorborne disease surveillance programs $(8,9)$. In some cases, programs will need to be implemented in new regions; in others, climate change may reduce current infectious disease burdens. The degree to which programs and measures will need to be augmented to address the additional pressures caused by climate change will depend on factors such as the current burden of climate-sensitive diseases; the effectiveness of current interventions; projections of where, when, and how the burden of disease could change with changes in climate and climate variability; the feasibility of implementing additional cost-effective interventions; other stressors that could increase or decrease resilience to impacts; and the social, economic, and political context within which interventions are implemented (8). Strengthening health systems will enable them to deal with both gradual changes in climate as well as sudden impacts (such as extreme weather events).

\section{Future climate change will depend on the choices made in the next few years}

As mentioned previously, Figure 2 shows projected temperature changes over this century based on different scenarios of greenhouse gas emissions (7). The scenarios include future demographic, economic, and technology changes that determine the amount of fossil fuels that will be burned. All of these changes are the result of human choices, including individual and collective choices related to energy efficiency, as well as national choices on investments in technology. Because of the inertia in the climate system, the choices made in the next few years will affect the rate and magnitude of climate change for our children and grandchildren.

\section{REFERENCES}

1. Confalonieri U, Menne B, Akhtar R, Ebi KL, Hauengue M, Kovats RS, et al. Human Health. In: Parry ML, Canziani OF, Palutikof JP, van der Linden PJ, Hansson CE, editors. Climate Change 2007: Impacts, Adaptation and Vulnerability. Contribution of Working Group II to the Fourth Assessment Report of the Intergovernmental Panel on Climate Change. Cambridge, U.K.: Cambridge University Press, 2007; p. 391431.

2. Ebi KL, Balbus J, Kinney PL, Lipp E, Mills D, O’Neill MS, Wilson M. Effects of global change on human health. In: Gamble JL, editors. Analyses of the Effects of Global Change on Human Health and Welfare and Human Systems. A Report by the U.S. Climate Change Science Program and the Subcommittee on Global Change Research. Washington, DC: U.S. Environmental Protection Agency, 2008, pp 2-1 to 2-78.

3. Kovats $\mathrm{S}$ (Ed.). Health Effects of Climate Change in the UK 2008: An Update of the Department of Health Report 2001/2002. London, UK: U.K. Department of Health / Health Protection Agency, 2008.

4. Seguin J, Berry P. Human Health in a Changing Climate: A Canadian Assessment of Vulnerabilities and Adaptive Capacity. Synthesis Report. Ottawa, Canada: Health Canada, 2008.

5. Ontario College of Family Physicians (OCFP). Addressing the 
Health Effects of Climate Change: Family Physicians Are Key. Toronto, Canada, 2008.

6. Burroughs WJ. Changing weather. In: Burroughs WJ, editor. Weather. Sydney, Australia: The Nature Company Guides / Time-Life Books, 1996.

7. Intergovernmental Panel on Climate Change (IPCC). Climate Change 2007: The Physical Science Basis. Summary for Policymakers. Contribution of Working Group I to the Fourth Assessment Report. Cambridge, U.K.: Cambridge University Press, 2007.

8. Ebi KL, Smith J, Burton I, Scheraga J. Some lessons learned from public health on the process of adaptation. Mitigation and Adaptation Strategies for Global Change 2006;11:607-620. doi:10/1007/s11027-006-3257-7.
9. Frumkin H, Hess J, Luber G, Malilay J, McGeehin M. Climate change: the public health response. Am J Public Health 2008; doi:10.2105/AJPH.2007.119362

10. Woodward A, Hales S, Weinstein P. Climate change and human health in the Asia Pacific region: who will be the most vulnerable? Clim Res 1998;11:31-7.

11. Fleury M, Charron DF, Holt JD, Allen OB, Maarouf AR. A time series analysis of the relationship of ambient temperature and common bacterial enteric infections in two Canadian provinces. Int J Biometeorol 2006: DOI 10.1007/s00484-006-0028-9.

12. Nakicenovic N, Alcamo J, Davis G, de Vries B, Fenhann J, Gaffin S, et al., editors. Special Report on Emissions Scenarios. Cambridge, U.K.: Cambridge University Press, 2000.

Kristie L. Ebi is Executive Director of the Technical Support Unit for Working Group II (Impacts, Adaptation, and Vulnerability) of the Intergovernmental Panel on Climate Change (IPCC). Prior to this position, she was an independent consultant. She has been conducting research on the impacts of and adaptation to climate change for more than a dozen years, including on extreme events, thermal stress, foodborne safety and security, and vectorborne diseases. She has worked with the World Health Organization, the United Nations Development Programme, USAID, and others on implementing adaptation measures in low-income countries. She facilitated adaptation assessments for the health sector for the states of Maryland and Alaska. She was a lead author on the "Human Health" chapter of the IPCC Fourth Assessment Report, and the "Human Health" chapter for the U.S. Synthesis and Assessment Product "Analyses of the Effects of Global Change on Human Health and Welfare and Human Systems." She has edited fours books on aspects of climate change and has more than 80 publications. Dr. Ebi's scientific training includes an M.S. in toxicology and a Ph.D. and a Masters of Public Health in epidemiology, and two years of postgraduate research at the London School of Hygiene and Tropical Medicine. 